\title{
SUPPLEMENTS TO JOHANNES GUTSLAFF'S TERM CREATION
}

\author{
Kristiina Ross \\ Institute of the Estonian Language
}

\begin{abstract}
After the Reformation, two written languages developed in the Estonian territory: one was based on the South-Estonian dialects, and the other on the North-Estonian dialects. By the 1630s, year-round pericope books had finally been printed in both language versions. The new aim in the mid-seventeenth century was to translate the whole Bible, as well as to homogenise and systematise the already existing work. Term creation became especially important. At that point, Estonian lacked equivalents of many essential abstract notions, the terminology of the Old Testament was hopelessly fragmentary, and the usage of a number of terms was unstable. The first person to undertake the translation of the whole Bible was Pastor Johannes Gutslaff, who worked in Urvaste in South-Estonia. His translation remained in manuscript and later Bible versions show no traces which would indicate that his work was used. Gutslaff's translation is an interesting and instructive example of a missed opportunity in the history of the Estonian written language. The following characterises Gutslaff's language creation in general and describes his search for Estonian equivalents of two New Testament terms ( $\beta \lambda \alpha \sigma \varphi \eta \mu i \alpha$ 'blasphemy' and $\tau \varepsilon \lambda \omega v \eta \varsigma$ 'publican'). The matches suggested for the first term are quite transparent, whereas those for the second have a vaguer etymology.
\end{abstract}

Keywords: history of written Estonian, Bible translation, terminology, blasphemy, publican

\section{Introduction}

After the Reformation, two written languages developed in the Estonian territory: one was based on the South-Estonian dialects, and the other on the North-Estonian dialects. Although the full Estonian-language Bible was published only in 1739, in the language version based on North-Estonian dialects, in the 17 th century attempts were made in both written languages. 
By the end of the 1630s, year-round pericope books had been published in both language versions (Rossihnius 1632 and Stahl 1638). These probably relied on earlier manuscripts and, for example, Stahl's material is quite heterogeneous. The language of both pericope books is remarkably German-biased, and can be literally traced to Martin Luther's German Bible text. In the first half of the 17th century, the terms, too, were in most cases simply transferred from Luther's German, except for some main terms, which had probably appeared in the language before the Reformation through Latin or even earlier via Swedish or Church Slavonic, and thus do not necessarily conform to the German system. From the mid-century, the new aim was to translate the whole Bible, as well as to homogenise and systematise the already existing work. Term creation became crucial, as at that point Estonian lacked equivalents of the majority of Old Testament terms and many essential abstract notions, and the usage of a number of terms was unstable (Masing 1975). After the most important texts had been translated via German, the issue of using source texts in their original languages emerged. This caused further confusion, as Martin Luther's German equivalents do not often systemically suit Hebrew and Greek source terms. Discussions of the Estonian language intensified in the 1680s, when the first translation of the New Testament finally appeared in South-Estonian (1686), and heated debates broke out about editing the North-Estonian version.

The first to undertake the translation of the whole Bible, in mid-century, was Pastor Johannes Gutslaff, who worked in Urvaste in South-Estonia. His translation was probably carried out between 1647 and 1657, although it remained in manuscript, and later translations have not revealed any impact from it. Johannes Gutslaff (?-1657) came from western Pomerania in Germany. He arrived in Livonia after his studies at Greifswald and Leipzig Universities and enrolled in Tartu University in 1639 (Tering 1979: 26-27). Probably in spring-summer 1641 (Tering 1979: 28-29, and Kõiv 2006: 202-207), he took up his job as pastor in Urvaste, where he worked until 1656, when he fled to Tallinn to avoid warfare. The next year (1657) Gutslaff died of 
plague in Tallinn. He left two printed books and his Bible translation in manuscript to Estonian cultural history. His printed books have, to some extent, been examined and contextualised from the cultural-historical perspective. The German-language Kurzer Bericht vnd Vnterricht Von der Falsch-heilig genandten Bäche in Lieffland Wöhhanda... was published in 1644 and is regarded as one of the most fascinating texts describing the local conditions at the time, thus being of interest to history, language and folklore researchers (Kõiv 1997). The first South-Estonian grammar, with the main text in Latin, Observationes grammaticae circa linguam esthonicam (1648) has been characterised as a manifestation of a missionary-linguist which also expresses an original view of language (Lepajõe 1998). Gutslaff's Bible translation, however, has hardly been studied at all. There is only one treatment, comparing the description of a verb form in Gutslaff's grammar and its occurrence in the Old Testament translation (Peebo 1995). Preliminary generalisations on the language of Gutsalff's translation have been published in an overview article (Ross 2009b).

The translation has survived in two manuscripts of different origin. The Old Testament is a clean copy in Gutslaff's own handwriting. It covers about one third of the canonical books (the manuscript ends with 1 Kings 1:33) and contains, in addition to the translated text, the translator's comments in Latin and German on some Hebrew words and expressions. The manuscript is in the Estonian Literary Museum (register no 1950/37). The New Testament translation has survived in H. Göseken's rewriting and was identified (at first as a speculation) only in 2006 (Tafenau 2006: 263-264). The manuscript contains the text of the entire New Testament (although some parts are lost) and some brief comments in the margins, probably by $\mathrm{H}$. Göseken, mostly parallel equivalents. The manuscript is kept in the Estonian Historical Archives (1187-2-5323). The entire surviving part of Gutslaff's translation is electronically available on the homepage of the Institute of Estonian Language in the concordance of the history of Estonian Bible translations (http://portaal. eki.ee/piibel). A publication of facsimiles and rewritings of man- 
uscripts of the First Book of Moses and the Gospel of Matthew is being prepared.

On the basis of a few examples, the following examines Gutslaff's usage of terms, in order to find possible explanations of why his work was never developed further. The correspondence of later translators mentioned Gutsalff's version of the Old Testament as a possible aid or a source text as late as the beginning of the 18th century (Tafenau 2009: 691). His translation was again discussed in the 19th century, no longer as a possible source text in translation, but as a cultural and historical research topic and an object of interest. In 1925-1927, Albert Saareste and A. R. Cederberg published eight chapters from its various parts (Valik 1992: 102-127). According to R. Põldmäe, Gutslaff's grandson, Eberhard Gutsleff Jr., donated his grandfather's Bible translation to J. Ch. Quandt in 1737 (Põldmäe 2011: 48). This hopefully suggests that, through J. Ch. Quandt, something of Gutslaff's translation language could have reached the Moravian language usage, but this is still waiting to be researched.

\section{The linguistic overview of Gutslaff's Bible translation}

Gutslaff's Bible translation was the first translation in Estonian that contained both the New and the Old Testament. Nevertheless, he did not start from scratch, especially with the New Testament. As mentioned above, pericope books were published in the 1630s, both in the South- and North-Estonian languages. In the early 1640s, the Bishop of Estonia, Joachim Jhering, organised the translation of the New Testament in North-Estonian, and allegedly managed to get the complete manuscript, although the translation has not survived. In South-Estonia, J. Rossihnius's church handbooks (1632) laid a systematic foundation for the written tradition (Kingisepp et al. 2002: 11-12) and, as seen in the "Introduction to the Reader" in Gutslaff's grammar, he knew the language of Rossihnius's handbook quite well. When he was writing the grammar, he seemed to think that Rossih- 
nius's language did not correspond precisely enough to local dialects. For example, he pointed out that the local dialect had no ending $t$ in the nominative of the noun in plural and in the plural form of the 3rd person of the verb. The ending $t$ was typical of North-Estonian dialects, but Rossihnius used it in his translations as well. Gutslaff explained that he wished to see the local dialect emerge as pure ${ }^{1}$ (Gutslaff / Lepajõe 1998: 32, 34). In his grammar rules and paradigms, he indeed presented these forms without $t$, e.g. Sullasi 'servants', Mäji 'mountains', and Nemma Tachtwa 'they want' (cf. Rossihnius's sullased (Mt 13:28 etc.), mäghed (Js 40:4), and tachtwat (Lk 16:26)). In the introduction, the problem of the relationship of grammar rules to the living dialect is discussed in connection with other forms and morphosyntactic constructions as well. In his Bible translation, he returned to the tradition of Rossihnius in the above-described forms, and used (the North-Estonian) $t$ in both forms: sullaset 'servants' and tahchtwat '(they) want'. There are also other differences between the language described in the grammar and the language used in the Bible translation. This allows us to assume that the Bible translation language reflects Gutslaff's later linguistic views. He had already started translating the Old Testament before the grammar was published (Tering 1979: 30), but the translations that formed the basis for the surviving Old Testament rewriting and the New Testament copy recorded by Göseken clearly date from the post-grammar period. At any rate, the discussions in the introduction to the grammar, and the changing practical language use prove that Gutslaff purposefully dealt with the issues of the functional peculiarities of spoken and written languages and tested various methods of employing grammatical patterns of oral dialects in written translation.

Gutslaff intended to translate from the original languages (ex fontibus) (Tering 1979: 30), and the analysis so far has indeed shown that the Old Testament translation largely follows the Hebrew original's phrase-structure, and the New Testament translation relies on Greek, although Martin Luther's German translation was naturally available as well. Grammatical analy-

1 Et ideo ut pura in lucera veniat haec Dialectus nostra, laboro et opto. 
sis suggests that Gutslaff occasionally approached the translation language rather creatively, trying to find South-Estonian dialectal grammar equivalents of some Greek morphosyntactic constructions (Ross 2009a: 899-902). His language, however, also contains grammatical forms that seem to have been mechanically compiled from those used in the earlier written language and oral popular language. For example, he uses tuts-ending participles in constructions such as sunnituts sahma (Gen 4:15). The construction generally corresponds to the German werdenpassive (cf. the same expression of Luther's, gerochen werden), but Gutslaff uses this a great deal independently of Luther's text as well. The participle's specific phonetic form was probably taken from Rossihnius's (North-Estonian) tut-ending participle and the $t u s-/ n u s$-ending participle form with a translative meaning, used in oral popular language together with the saama-verb (see more Ross 2009b: 17).

Gutslaff also shows similar inventiveness and bold innovation in his term creation.

His approach to this area is made clear in the Old Testament translation commentaries on Hebrew words and their translation equivalents. In Gen 1:6, for example, a comment is added to the Hebrew word רִִ רִיע 'firmament', which Luther had translated with the word Feste, derived from the Latin equivalent firmamentum. ${ }^{2}$ Gustlaff uses the word väljavenitamine 'stretching out', and explains: "In Hebrew רִָָ רִיט oxeans 'stretching out' from the word רָז 'expanded, opened'. Greeks call it $\sigma \tau \varepsilon \rho \varepsilon \dot{\varepsilon} \omega \mu \alpha$, which in Latin means 'firmamentum' and in German 'eine Feste'. I preferred to express it according to Hebrew ütz weljawinnitaminne 'eine aussdehnung [a stretching out]' than according to Hebrew ütz kinnitaminne 'eine Feste'.'” The 17th

2 Here and henceforth (except in sub-section 3.2) the terms are presented in generalized context in today's phonetic form and orthography. The referred quotations present Gutslaff's examples after the original manuscripts (Gutslaff OT, Gutslaff NT), Martin Luther's translation after Luther's 1545 publication. The quotations of the Greek original (GO) and the authorized translation (KJV) use web version.

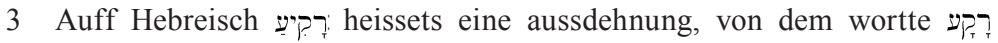
expandit, diduxit. Die Grichen heissen es $\sigma \tau \varepsilon \rho \varepsilon \dot{\omega} \omega \mu \alpha$, welches auff Latei- 
century North-Estonian language tradition used the Lutherbased term kinnitus; the father and son Virginius's rewriting of the Old Testament translation initially (Gen 1:6, 7, 8) used the derivative laotus, which relies on the same semantic link as Gutslaff, although it was derived from a different stem. This was also accepted in the printed Bible version and is still used today (Uibo 2009).

The most remarkable invention is Gutslaff's equivalent of the Greek verb $\beta \alpha \pi \tau i \zeta \omega(<\beta \dot{\alpha} \pi \tau \omega)$ 'baptise', and of the whole New Testament term family derived from it ( $\beta \dot{\alpha} \pi \tau \imath \sigma \mu \alpha, \beta \alpha \pi \tau \iota \sigma \mu o ́ \varsigma$ 'baptism', and $\beta \alpha \pi \tau \imath \sigma \tau \eta$ ' 'baptist'). He conveys this via the word family formed from the stem kasta- 'to dip' (kastma 'baptise', kastmine 'baptism' and kastja 'baptist'). On the basis of the existing data, this term family has been conveyed in the entire Estonian-language religious literature by the root risti-: ristima 'baptise', ristimine 'baptism' and ristija 'baptist', starting with the very first 16th century transcripts. Gutslaff's New Testament has survived in an unfamiliar rewriting and without comments, but we may assume that the equivalent kasta- was the result of argumentations analogous to the Old Testament commentaries. Both the Greek verb and its German equivalent taufen contain an allusion to a water ritual; the Estonian term risti-, probably borrowed from Slavonic, has no such semantic connection and it is instead phonetically associated with the words rist ('cross') and Kristus ('Christ') (Metsmägi et al. 2012 sub. rist, risti- and ristima). As seen in the vocabulary of Gutlsaff's grammar, the traditional Estonian term was known to him, but because of its semantic links he evidently regarded it as unsuitable, and decided to replace it with a better term (see more Ross 2009b: 20-22).

nisch Firmamentum, vndt auff deutsch eine Feste, heisset. Ich hab es lieber wollen nach dem Hebreischen geben, ütz weljawinnitaminne, eine aussdehnung, alss nach dem Grichischen, ütz kinnitaminne, eine Feste. 


\section{Additional examples of Gutsalff's term creation}

\section{1. sõimuse pajatus $\sim$ naerupajatus $<\beta \lambda \alpha \sigma \varphi \eta \mu i ́ \alpha$ ('Gotteslästerung', 'blasphemy')}

In most cases, it is fairly easy to guess how Gutslaff derived the equivalents on the basis of derivational connections of the original language. For example, in the part of letters, Gutslaff's equivalent of the Greek word $\beta \lambda \alpha \sigma \varphi \eta \mu i \alpha$ 'blasphemy' is the word sõimus, a derivative of the verb sõimama 'to call names, scold'. However, the surviving parts of the Gospels have the equivalents sõimuse pajatus 'saying of scolding' (Mt 12:31 (twice), Mt 15:19), naeru pajatamine pajatus 'saying of laughter' (Mt 26:65, Mk 2:7, 3:28) and Jumala naermine 'laughing at God' (Jh 10:33). Luther's equivalent of this word was mainly Lästerung, a derivative of the verb lästern 'slander, blaspheme', and Gutslaff's sõimus can easily be interpreted as an equivalent of the German word. In the Gospels (except in Mt 12:31 and Mt 15:19), Luther adds the attribute Gottes to the German term, which clearly explains that the object of slander is God, although the Greek original does not lexically refer to God, and $\mathrm{KJV}$, too, does not deem it necessary to explain its Greek-loaned equivalent. Gutslaff's equivalent in the Gospel of John can thus also be explained as deriving from the German translation: Jh 10:33 Gutsalff's NT se Jumala nahrmisse perrast < Luther 1545

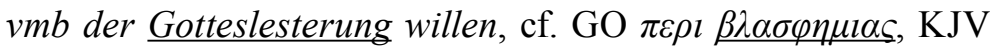
for blasphemy. In the noun phrases sõimuse pajatus and naeru pajatus pajatamine in the Gospels of St Matthew and St Mark, Gutlsaff was probably trying to convey the derivative nuances of the Greek term. The Greek word comes from the verb $\beta \lambda \alpha \dot{\alpha} \tau \omega$ 'hinder, injure, hurt' and the substantive $\varphi \dot{\eta} \mu \eta$ 'rumour, fame', which in turn comes from the verb $\varphi \eta \mu i$ 'to affirm, say' (http:// www.biblestudytools.com/lexicons/greek/nas/), and on the basis of these etymological connections, Gutslaff produced a term that is a combination of the two words, e.g. Mt 12:31 Gutsalff NT se seumusse pajatus se pöha waimo Pähle 'the saying of scolding on the Holy Spirit' (cf. Luther 1545 die Lesterung wider 
den Geist, GO $\tau$ ov $\pi v \varepsilon v \mu \alpha \tau o \varsigma \beta \lambda \alpha \sigma \varphi \eta \mu \imath \alpha, \mathrm{KJV}$ the blasphemy against the Holy Ghost, Mt 26:65 Gutslaff's NT ollete teije t. nahro pajatamisst Kuhlnut 'you have heard his saying of laughter' (cf. Luther 1545 habt jr seine Gotteslesterung gehört, GO $\eta \kappa о v \sigma \alpha \tau \varepsilon \tau \eta v ~ \beta \lambda \alpha \sigma \varphi \eta \mu \imath \alpha v$, KJV you have heard his blasphemy).

In later Estonian translation history, both the South- and North-Estonian languages conveyed the term with teotus (less frequently also teotamine), a derivative of the verb teotama 'to dishonour, insult' (in one manuscript the word laitmine 'blaming' was used - Põhjaeesti 2007 : 52), whereas in the text of the Gospels this was usually supplemented by the word form Jumala (the genitive of Jumal 'God'). In the printed Bible in 1739, and in its second print in 1773, the attribute Jumala missing in the original text was added in smaller script (as were all words added for the clarification of the text), although in later translations using a different script was abandoned. Modern translations have replaced Jumala with genitive forms of the word pühadus 'holiness', e.g. Jh 10:33 pühaduseteotuse pärast (http://www.piibel. org/?rmt=Jh\&ptk=10), because teotus alone evidently seems too general as an equivalent of $\beta \lambda \alpha \sigma \varphi \eta \mu i \alpha$.

\section{2. jähvkemehs $<\tau \varepsilon \lambda \omega v \eta \varsigma$ ('Zöllner', 'publican')}

Some of Gutsalff's translation equivalents, however, are hopelessly vague, at least to the modern reader. The most mysterious seems to be his equivalent of the NT term $\tau \varepsilon \lambda \omega \omega^{\prime} \eta \varsigma(\mathrm{Lu}$ Zöllner, KJV publican), which he conveys (alternately written in one or two words) by the collocation jähvke mehs (e.g. Mt 10:3). The 17th century North-Estonian translations used the German loan word tölner. This is still used today, but only in the narrow Biblical sense. The equivalent was present as early as in Georg Müller's sermons (Habicht et al 2000: 375), Heinrich Stahl's pericopes and in later North-Estonian translations (e.g. Lk 18:10 Stahl 1638, Põhjaeestikeelsed 2007: 172-173). The same word was used by J. Rossihnius, Gutslaff's predecessor in the SouthEstonian written language tradition (Kingisepp et al 2002: 395). 
The post-Gutslaff South-Estonian tradition adopted, beginning with the 1686 New Testament, the word müütnik (e.g. NT 1686 Lk 18:10 Mühtnik). According to Paul Ariste, the South-Estonian term is a Latvian loan based on the Latvian word muitnieks, which in turn is derived from the Slavonic loan muita 'customs' (Ariste 2010). (In Russian, the Old Slavonic Mblmapb, derived from the same root (Mblmo 'customs'), is today used only as a Biblical term.)

Gutslaff also uses the word jähvke as an equivalent of the examined Greek term's source word $\tau \dot{\varepsilon} \lambda o \varsigma$ in the few cases where the latter means 'customs' (Mt 17:25 wötwat neht JähvKet, Lu nemen den zol, KJV take custom, Gr $\lambda \alpha \mu \beta \alpha v o v \sigma l v \tau \varepsilon \lambda \eta)$. As we can see, Luther's translation preserves the Greek original's derivative connection between the words $\tau \dot{\lambda} \lambda o \varsigma$ and $\tau \varepsilon \lambda \omega \nu \eta \varsigma$ (Zoll - Zölner); the connection is also maintained in the Latvian translation (muita - muitnieks). KJV abandons this connection, translating the words respectively as custom and publican. The connection had already been broken by the Vulgate, which uses tributus (Mt 17:25) and vectigal (Rm 13:7) as equivalents of $\tau \dot{\varepsilon} \lambda o \varsigma$ in the meaning 'customs, tax', and publicanus as the equivalent of $\tau \varepsilon \lambda \omega v \eta \varsigma$. The connection was also ignored by the (generally quite Luther-true) Swedish tradition (tull - Publican), the Finnish tradition (tulli - publikaani) and the 1686 SouthEstonian translation (toll - müütnik). Gutslaff decided to keep the connection and derived an equivalent of the term $\tau \varepsilon \lambda \omega v \eta \varsigma$ from the Estonian equivalent of the word $\tau \varepsilon \dot{\lambda} \propto \varsigma$, adding the word mees 'man, human being' to denote the agent. But where Gutslaff actually found the word jähvke as an equivalent of $\tau \varepsilon \dot{\lambda} \partial \varsigma$ in the meaning 'customs' is much more complicated; it is even unclear how this word should be morphophonologically interpreted.

From the morphophonological point of view, the sequence jähvke could be - with some difficulties - interpreted as a deverbal noun derived from the verb jääma 'to remain, stay' with the suffix $k$, i.e. as an equivalent of the word jääk 'rest, remainder, residue' of modern Estonian. In his grammar book, Gutslaff described the equivalents of the modern $k$-deverbals as $k e$ deverbals, claiming that these deverbals expressed doing some- 
thing and corresponded to Latin tus-, sus- and xus-deverbals, ${ }^{4}$ and illustrating his claim with the words Söke (modern Estonian söök 'food, nutriment' from the verb sööma 'to eat'), Joke (jook 'drink' from the verb jooma 'to drink'), Löke (löök 'blow, beat' from the verb lööma 'to beat') and kewke (käik 'gait, course' from the verb käima 'to go, walk') (Gutslaff / Lepajõe 1998: 8283). However, the interpretation of the part of the sequence preceding the suffix remains problematic. According to the rules Gutslaff himself presents in his grammar book, this part should be a pure verbal root. We can assume that the letter $h$ in the sequence jähvke marks the length of the preceding vowel, as it generally does in the manuscript under discussion. But the letter $v$ still remains without a reasonable explanation. It could mark the second component of a diphthong, as its parallel variant $w$ obviously does in the deverbal noun kewke 'käik'. In this case, according to the derivative scheme in Gutslaff's grammar book, the verbal root should contain the same diphthong (cf. kewma), but the root of the verb jääma has no $v / w$-component, neither in the spelling in Gutslaff's grammar book nor in his translation (in the grammar, the verb root is spelled $j \ddot{a}$-, and in the translation $j a ̈ h-)$. Besides, it is unclear why Gutslaff uses $v$ in this word instead of the more common $w$. The letter $v$ sometimes indicates a Latin or Greek loan, as in the word evangeelium 'Gospel' (e.g. Mt 4:23 Evangeliummit). Still, the phonetic structure of the discussed word makes it difficult to interpret it as a Latin (or Greek) loan. We have to be very cautious in interpreting the spelling system of Gutslaff's New Testament. On the one hand, we cannot rely on the rules of spelling given in his grammar book because, as the manuscript of the Old Testament indicates, after the publication of the grammar book Gutlsaff's views on spelling changed radically. On the other hand, as the translation of the New Testament survives in the form of a copy not written down by Gutslaff himself, we cannot really rely on the spelling system of the Old Testament either. Nevertheless, it is worth mentioning that $v$ is used instead of $w$ at least once in a similar

4 Substantiva in ke /actum signantia, quae respondent Latinorum verbalibus in Tus, Sus, Xus. 
context in the Old Testament as well, namely in Gen 4:22 rahvda (the partitive singular form of the word raud 'iron'), where it possibly indicates the vowel $u$ following the long $a$.

Before looking for other possible interpretations of the letter $v$ in the sequence jähvke, let us examine the semantic aptness of the deverbal jääk as an equivalent of the Greek $\tau \dot{\varepsilon} \lambda o \varsigma$. The word $\tau \varepsilon \dot{\lambda} \lambda o \zeta$ in the New Testament has two meanings. The first, the more abstract and general, has several sub-meanings: I. end a) termination, the limit at which a thing ceases to be (always of the end of some act or state, but not of the end of a period of time), b) the end 1. the last in any succession or series 2 . eternal, c) that by which a thing is finished, its close, issue, and d) the end to which all things relate, the aim, purpose, II. toll, custom (i.e. indirect tax on goods) (http://www.biblestudytools.com/lexicons/greek/nas/ telos.html). In order to render the first meaning of the word, Gutslaff uses (in accordance with the 17th century tradition, which survived in the Estonian Bible translation until the middle of the 20th century) the equivalent ots, some of the modern meanings of which are ' 1 . the highest part, 3. the first part, 5. the last part, and 6. (in compound words) the part left over' (EKSS). The earlier meaning of the word is now expressed by the word lõpp, but as late as the second half of the 19th century the meaning of ots was still described as Ende (sowohl erstes als letztes, also Anfang und Schluss), Spitze, Gipfel, Stirn, Ausgang (einer Sache), Uebriggebliebenes, Stückchen (Wiedemann 1869: column 789). The translation of the first meaning of $\tau \dot{\varepsilon} \lambda o \varsigma$ as ots is in accordance with Luther's equivalent das Ende and the equivalent of KJV end (cf. e.g. Mt 10:22 Ke Kannatab otzani, Lu bis an das ende beharret, $\mathrm{KJV}$ he that endureth to the end). On the other hand, the word ots is partly synonymous with the word jääk, as indicated by the submeaning of ots, 'the part left over', becoming evident in modern compound words and in the 19th century German equivalent 'Übriggebliebenes'. ${ }^{5}$ Without additional data, it is difficult to say

5 Although today's synonym dictionaries do not bring together words ots and jääk, their partial synonymity is at least presented in the EnglishEstonian online dictionary (http://portaal.eki.ee/dict/ies/), where both are given as equivalents of the English word: end-lópp, ots, jääk, eesmärk. 
which semantic links Gutslaff actually had in mind in using the $k e$-deverbal of the verb jä̈̈ma to express the second meaning of the Greek word $\tau \dot{\varepsilon} \lambda o \varsigma$. It nevertheless seems quite possible that he tried to preserve some kind of connection between the two Estonian equivalents of the Greek $\tau \dot{\lambda} \lambda o \varsigma$, and thus chose a synonym of the first equivalent to express the second meaning. It is not possible to say whether there existed a $k(e)$-deverbal of the verb jääma in the Urvaste dialect contemporary to Gutlsaff, or whether he derived this word himself on the basis of the existing deverbals söök, jook, löök and käik.

In spite of the fact that the deverbal jääk from the verb jääma could thus semantically indeed express the second meaning of the Greek word $\tau \dot{\varepsilon} \lambda o \varsigma$, these considerations do not help to explain the letter $v$ in Gutslaff's spelling jähvke. Recalling the technique Gutslaff used to build tuts-forms described above, it seems quite possible that he might have taken this $v$ from some other word and mechanically added it to his newly derived noun. Although it seems that Gutslaff generally relied on the original languages (Hebrew and Greek) in his term creation, Latin should not be left out of consideration. The Latin equivalent of

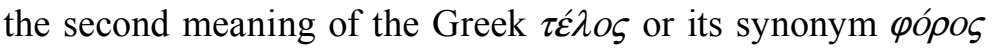
is tributum, which is a deverbal from the verb tribuo 'to divide'. The Estonian equivalents of tribuo are jaga(ma) and jao(tama). In dialects, the corresponding stems may appear as jäga- and jäu-. So Gutslaff could have put together the root with a long $\ddot{a}$ ( $j \ddot{a} \ddot{a}-$ ), which is semantically equivalent to the Greek word, and the root with the diphthong (jäu-), semantically equivalent to the Latin word, and have added the suffix $k e$, which in his spelling would exactly result in jähvke.

The above discussion assumes that Gutslaff created the terms jähvke and jähvke mehs for customs and publican himself in the course of translating, relying on the semantic system of the original language of the New Testament. Naturally, it cannot be excluded that the 16th-century Urvaste dialect contained the verb *jäuma (with suitable meaning to derive a $k(e)$-deverbal) or even the deverbal *jäuk 'customs' itself, and that there are simply no traces of it left in the later writings. 


\section{Conclusion}

Johannes Gutslaff was the first to try to translate the entire Bible into Estonian. As a user of the South-Estonian written language, he was partially able to rely on the earlier tradition, which had been created by J. Rossihnius and his pericope book in 1632 . Gutslaff, however, did not rigorously observe Rossihnius's tradition in his grammar and Bible translation, but instead showed a remarkably creative spirit both in grammatical forms and in term creation, trying to find new and better means of expression. In term creation, he relied on the word's semantic links in the original language, as clearly seen in some of his comments on Hebrew words and their equivalents in his Old Testament manuscript, and as confirmed by his translation equivalent of the New Testament term $\beta \alpha \pi \tau i \zeta \omega$ 'baptise'. The first term tackled in this article (the equivalent group of the term $\beta \lambda \alpha \sigma \varphi \eta \mu i \alpha$ ) shows that the choice of Gutslaff's translation equivalents can, on the whole, be easily deduced from the word etymology of the original language. The other example group (the equivalents of $\tau \dot{\varepsilon} \lambda o \varsigma$ 'customs' and $\tau \varepsilon \lambda \omega \nu \eta \varsigma$ 'publican') probably illustrates Gutslaff's boldness in contaminating, as phonetically his equivalent jähvke of the word $\tau \varepsilon ́ \lambda o \varsigma$ cannot be directly derived from the assumed source verb jääma 'to stay', but the element shown as $v$ possibly comes from another verb. Another explanation could be that jähvke was used as an equivalent of the Latin term distributum and was thus derived from the verb jaotama/jäutama 'to divide'. The ambiguity of the term could be telling in trying to understand why the later Bible translators did not make use of Gutslaff's work. No doubt, there must have been other reasons why his translation was ignored, and the fact that the later version - with no genetic connection to Gutslaff's translation - became valid as the South-Estonian written language was in the end probably caused above all by extralinguistic factors. However, the fate of Gutslaff's translation could have partly been determined by his linguistic stubbornness and his radical attempt to forcefully adapt the target language to the derivative and semantic connections of the source languages (Hebrew and Greek), ignoring the existing tradition. 


\section{Acknowledgement}

The study was supported by the Estonian Ministry of Education, Research project no SF0050037s10 and Grant no 7896 of the Estonian Science Foundation.

\section{Address:}

Kristiina Ross

Institute of the Estonian Language

Roosikrantsi 6

10119 Tallinn, Estonia

E-mail: Kristiina.Ross@eki.ee

\section{Sources}

EKSS = Eesti keele seletav sõnaraamat (http://www.eki.ee/dict/ekss/).

$\mathrm{GO}=$ Greek Original (http://www.bibelwissenschaft.de/index.php?id=1820).

Gutslaff NT $=$ Manuscript of New Testament. Estonian Historical Archives (1187-2-5323).

Gutslaff OT $=$ Manuscript of Old Testament. Estonian Literay Museum (1950/37).

Gutslaff, Johannes / Lepajõe, Marju (1998) = Johannes Gutslaff, Observationes grammaticae circa linguam esthonicam / Grammatilisi vaatlusi eesti keelest. Tõlkinud ja väljaande koostanud [Translated and compiled by] Marju Lepajõe. (Tartu Ülikooli eesti keele õppetooli toimetised 10.) Tartu.

KJV = King James Version (http://www.bibelwissenschaft.de/online-bibeln/ englische-bibel-kjv/lesen-im-bibeltext/).

Luther 1545= Biblia. Das ist: Die gantze Heilige Schrifft / Deudsch / Auffs new zugericht. D. Mart. Luth. Begnadet mit Kurfürstlicher zu Sachsen Freiheit. Gedruckt zu Wittemberg / Durch Hans Lufft. M.D.XLV. (Facsimile edition. Berlin: Deutsche Bibelgesellschaft.)

NT $1686=$ Wastne Testament [New Testament] 1686. Eesti Keele Instituut. Tallinn: Eesti Keele Sihtasutus, 2001. (Facsimile edition.)

Rossihnius 1632 = Rossihnius, Joachim. Südestnische Uebersetzung des Lutherischen Katechismus, der Sonntags-Evangelien und -Episteln und der Leidensgeschichte Jesu nebst einem Anhang in das Südestnische übersetzter Kirchendlieder und Stücke der Agende mit einer Einleitung von Wilhelm Reiman. Verhandlungen der gelehrnten Estnischen Gesellschaft. 19. Band. Jurjew: H. Laakmann's Buch- und Steindruckerei, 1898. 
Stahl 1638 = Hand- vnd Hauszbuches Für die Pfarherren vnd Hausz-Väter Esthnischen Fürstenthumbs / Dritter Theil / Darinnen die gewöhnliche Evangelia vnd Episteln durchs gantze Jahr / zusampt der Historia des bittern Leidens vnd Sterbens vnsers HERRN Jesu Christi / In Teutscher vnd Esthnischer Sprache angefertiget / vnd auff eigenen Kosten zum Druck vbergeben / Von M. Henrico Stahlen / Pastoren an S. Catharinen Kirchen / Probste in Jerwen vnd Wirrland / vnd des Königl. Esthnischen Consistorij Assessoren. Revall: In Chr. Reusners Sel. Nachgelassener Widwen Drückerey / Im Jahr M. DC. XXXIIX.

Põhjaeestikeelsed 2007 = Põhjaeestikeelsed Uue Testamendi tõlked [NorthEstonian New Testament translations] 1680-1705. Luuka evangeelium. Apostlite teod. Koostanud [Compiled by] Kristiina Ross. (Eesti Keele Instituut.) Tallinn.

Valik 1992 = Valik eesti kirjakeele vanemaid mälestisi [Selected examples of old Literary Estonian] A. 1524-1739. Välja andnud [Edited by] Albert Saareste ja A. R. Cederberg. (Facsimile edition.) Tartu.

\section{References}

Ariste, Paul (2010) “Eesti müütnik”. In his Sõnalaenulõbu, 441-443. (Eesti mõttelugu, 96.) Tartu: Ilmamaa.

Habicht, Külli, Valve-Liivi Kingisepp, Urve Pirso, and Külli Prillop (2000) Georg Mülleri jutluste sõnastik. (Tartu Ülikooli eesti keele õppetooli toimetised, 12.) Tartu.

Kingisepp, Valve-Liivi, Külli Habicht and Külli Prillop (2002) Joachim Rossihniuse kirikumanuaalide leksika. (Tartu Ülikooli eesti keele õppetooli toimetised, 22.) Tartu.

Kõiv, Lea (1997) "Pilk 17. sajandi Liivimaa vaimuilma: Johannes Gutslaff. Kurtzer Bericht vnd Vnterricht uerber die falschheilig genandten Bache in Liefflant Woehhanda". Kleio. Ajaloo ajakiri 2, 9-15.

Kõiv, Lea (2006) "Johannes Gutslaff pastorina Urvastes". In Läänemere provintside arenguperspektiivid Rootsi suurriigis 16/17. sajandil II, 200-240. Koostanud [Compiled by] Enn Küng. Tartu: Eesti Ajalooarhiiv.

Lepajõe, Marju (1998) "Johannes Gutslaffi "Grammatilised vaatlused"”. In Johannes Gutslaff, Observationes grammaticae circa linguam esthonicam. Grammatilisi vaatlusi eesti keelest, 285-316. Tõlkinud ja väljaande koostanud [Translated and compiled by] Marju Lepajõe. (Tartu Ülikooli eesti keele õppetooli toimetised, 10.) Tartu.

Masing, Uku (1975) “Terminoloogia kujundamisest 17. sajandil”. Emakeele Seltsi aastaraamat 1973-1974 (Tallinn) 19-20, 151-168.

Metsmägi, Iris, Meeli Sedrik, and Sven-Erik Soosaar (2012) Eesti etümoloogiasõnaraamat. Tallinn: Eesti Keele Sihtasutus. 
Peebo, Jaak (1995) “Indikatiivi preesensi kolmas pööre Johannes Gutslaffil”. In Läänemere rahvaste kirjakeelte ajaloost, 116-129. Toimetanud [ed. by] Jaak Peebo. (Tartu Ülikooli eesti keele õppetooli toimetised, 1.) Tartu.

Ross, Kristiina (2009a) "Kirjaliku eesti lause poole". Keel ja Kirjandus 12, 889-907.

Ross, Kristiina (2009b) "Kõige vanemast tartukeelsest piiblitõlkest". Tartu Ülikooli Lõuna-Eesti keele- ja kultuuriuuringute keskuse aastaraamat (Tartu) 8, 11-26.

Tafenau, Kai (2006) "Eestikeelsetest Uue Testamendi tõlkekäsikirjadest Ajalooarhiivis". In Läänemere provintside arenguperspektiivid Rootsi suurriigis 16/17. sajandil II, 241-294. Koostanud (Compiled by) Enn Küng. (Eesti Ajalooarhiivi toimetised, 12.) Tartu: Eesti Ajalooarhiiv.

Tafenau, Kai (2009) "Veel täiendusi Vana Testamendi tõlkeloole". Keel ja Kirjandus 8-9, 688-708.

Tering, Arvo (1979) "Lisandusi ja täpsustusi Johannes Gutslaffi kohta". Keel ja Kirjandus 1, 26-30.

Uibo, Udo (2009) “Jumalik sõna taevalaotus”. Keel ja Kirjandus 8-9, 709-712. Wiedemann, Ferdinand Johann (1869) Ehstnisch-Deutsches Wörterbuch. St. Petersburg.

Kokkuvõte. Kristiina Ross: Lisandusi Johannes Gutslaffi terminiloome alalt. Alates reformatsioonist oli Eesti alal arendatud kahte kirjakeelt: üks tugines Lõuna-Eesti murretele, teine Põhja-Eesti murretele. 17. sajandi 30. aastatel jõuti kummaski keelevariandis aastaringsete perikoopide trükiväljaandeni. Sajandi keskpaigast peale sai sihiks kogu piibli tõlkimine ning ühtlasi senise töö ühtlustamine ja süstematiseerimine. Eriti oluliseks kujunes terminiloome. Seni puudus eesti keeles vaste paljudele olulistele abstraktmõistetele, väga lünklikult oli kaetud Vana Testamendi terminoloogia ning paljude piibliterminite korral oli kasutus kõikuv. Esimesena võttis terve piibli tõlkimise käsile ja viis suures osas ka lõpule Lõuna-Eestis Urvastes teeninud pastor Johannes Gutslaff. Tema tõlge jäi käsikirja ning hilisemates tõlgetes pole õnnestunud avastada mingeid jälgi, mis viitaksid tema töö kasutamisele. Niisugusena on Gutslaffi tõlge huvitav ja õpetlik näide ühest väljaarendamata jäänud võimalusest eesti kirjakeele ajaloos. Järgnevas iseloomustatakse Gutslaffi keeleloomet üldiselt ning kirjeldatakse tema vasteotsinguid kahele Uue Testamendi terminile ( $\beta \lambda \alpha \sigma \varphi \eta \mu i \alpha$ 'pühaduseteotus', $\tau \varepsilon \lambda \omega$ viऽ 'tölner'), millest esimesele pakutud vasted on kergesti läbinähtavad, teise vastepere aga hämarama etümoloogiaga.

Märksõnad: eesti kirjakeele ajalugu, piiblitõlge, terminoloogia, pühaduseteotus, tölner 
